\title{
Effects of Climate Change on Poultry Production in Benue State, Nigeria
}

\author{
J. A. C. Ezihe \\ Federal University of Agriculture, \\ Makurdi, Benue State. P.M.B 2373 Makurdi.

\section{A. Ali} \\ Federal University of Agriculture, \\ Makurdi, Benue State. P.M.B 2373 Makurdi.

\section{G. A. Ivom} \\ Federal University of Agriculture, \\ Makurdi, Benue State. P.M.B 2373 Makurdi.
}

\begin{abstract}
The study assessed the effects of climate change on poultry production in Benue State, Nigeria. One hundred and seventy nine (179) poultry farmers were interviewed to elicit relevant information in line with the objectives of the study. Descriptive statistics and inferential statistical tools were used for data analysis. Findings revealed that Majority (46.8\%) of all the poultry farmers fall within 21-40 years age bracket .This results imply that poultry farmers in the area were above the dependent age. The average age of the respondents was 39.1 years and within the economically active age range. Majority of $(52.5 \%)$ of the respondents were females and $47.5 \%$ were males. This means that poultry production is gender sensitive. The result showed that respondents have one level of education to the other, an indication that school leavers were no longer waiting for white kola jobs rather than engaged themselves in poultry production in the study area. The average start-up capital of the respondents was found

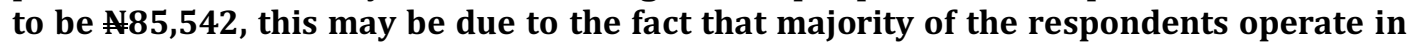
small scale. Close to half $(48.6 \%)$ of the respondents practiced intensive system of poultry production in the study area. with the mean years of awareness as 10.51. The findings further revealed that $90.9 \%$ of the respondents agreed that they are aware of climate change; this indicates that the majority of the poultry farmers in the study area have noticed variation in climatic elements. $85.9 \%$ of the respondents all agreed that temperature fluctuate in the study area. $72.6 \%$ of the respondents observed increased sunshine intensity in the study area and $76.3 \%$ agreed that distribution of rainfall follows normal distribution. $80.5 \%$ of the respondents agreed that global warming has effect on poultry production respectively. Inferential statistics shows that there is a significant relationship between respondents' socio - economic characteristics and perception of poultry farmers on effects of climate change on poultry production since $p>0.05(r=0.544, p=0.000)$. It is recommended extension agents and other development agencies need to educate the poultry farmers more about the effects posed by climate change on poultry production and intensify awareness campaign to poultry farmers on how to reduce the effects of climate change on poultry production.
\end{abstract}

Key words: Climate change, Poultry and Farmers Perception.

\section{Background to the Study}

\section{INTRODUCTION}

Poultry plays an important economic, nutritional and socio-cultural role in the livelihood of rural households in many developing countries, including Nigeria. Poultry are birds that include fowl, turkey, duck, goose, ostrich, guinea fowl, etc. which render not only economic 
services but contribute significantly to human food as a primary supplier of meat, egg, raw materials to industries (feathers, waste products), source of income and employment to people compared to other domestic animals (Demeke,2004). Poultry are efficient converters of feed to egg and meat within a short period of time. In terms of nutritive value, poultry egg rank second to cow milk. Agriculturists and nutritionists have generally agreed that developing the poultry industry of Nigeria is the fastest means of bridging the protein deficiency gap presently prevailing in the country (Amos, 2006). When ambient temperature is high, chickens have higher energy (feed) needs than when in thermo-neutral environments. Major losses result from a less efficient conversion of feed to meat, which detrimentally impacts poultry health and productivity (Olanrewaju et al., 2010). Poultry flocks are particularly vulnerable to climate change because there is a range of thermal conditions within which animals are able to maintain a relatively stable body temperature in their behavioural and physiological activities. Hence, birds can only tolerate narrow temperature ranges to sustain the peak of their production for human consumption and any unpredictable climatic changes will therefore trigger a series of adjustment and readjustments by livestock and poultry birds in the struggle for survival which may have negative consequence on the viability of poultry production. The environmental conditions affecting the performance and health productivity of chicken include temperature, relative humidity, light, sunshine prevailing at a given time, housing system and ventilation (Elijah and Adedapo, 2006). Ambient temperatures significantly influence the survivability and performance of the poultry production. According to Indian Council for Agricultural Research (ICAR, 2010), as the ambient temperature increased to _34oC the mortality due to heat was significantly high in meat type chickens by $8.4 \%$, the feed consumption of the chickens decreases from $108.3 \mathrm{~g} / \mathrm{bird} /$ day at $31.6 \mathrm{oC}$ to $68.9 \mathrm{~g} / \mathrm{bird} / \mathrm{day}$ at $37.9 \mathrm{oC}$, the egg production also decreased by $6.4 \%$ as compared to their standard egg production.

Climate as defined by Oyekale et al. (2009) is the state of atmosphere, which is created by weather events over a period of time. A slight change in the climate will affect agriculture.

According to Intergovernmental Panel on Climate Change (IPCC) report, the United Nations Framework Convention on Climate Change (UNFCCC) defines climate change as a change of climate which is attributed directly or indirectly to human activity that alters the composition of the global and/or regional atmosphere and which is in addition to natural climate variability observed over comparable time periods (IPCC, 2001). It is obvious from this definition that change is an inherent attribute of climate, which is caused by both human activities (anthropogenic) and natural processes (biogeographical) (Odjugo, 2009).

Climate change is already affecting people, their livelihoods and ecosystems and presents a great development challenge for the global community in general and for the poor people in developing countries in particular (Khanal, 2009). This also presents major challenges to scientists and policy makers.

Climate change alters global disease distribution, affects poultry feed intake, encourages outbreak of diseases which invariably affect poultry output (egg and meat) and also costs of production (Guis et al., 2011). Elijah and Adedapo (2006) reported in their study that high rainfall and relative humidity provide a conducive environment for breeding of parasites that cause outbreak of diseases which invariably reduces egg production. They further reported that temperature reduces the feed intake of poultry birds because more energy is needed to conserve the heat caused by high temperature, hence, a decreased in the rate of feed intake. Before now, Benue Sate has good climatic elements for poultry production especially its moderate temperature range. Research efforts on effects of climate change on poultry 
production will contribute positively to knowledge of the problem climate change poses to poultry sector that bears the contribution to the economy of the developing countries in the supply of protein to a large number of populations and also the source of livelihood for the rural populace. The broad objective of the study was to assess the effects of climate change on poultry production in Benue State, Nigeria.

\section{Objectives of the Study}

Specifically the objectives were to:

(i) describe socioeconomic characteristics of poultry farmers (respondents) in the study area;

(ii) perceived effects of climate change on poultry production pattern, and

(iii) determine the of level of awareness of poultry farmers on climate change.

\section{Statement of Hypothesis}

Based on the specific objectives the following hypothesis was stated and tested H01: there is no significant between selected socio-economic characteristics of poultry farmers and their perceived awareness on climate change

\section{METHODOLOGY}

The study was conducted in Benue State referred as "Food Basket of the Nation" is located in North Central of Nigeria. Benue state has 23 Local Government Areas administratively with Makurdi as its capital. Benue state is situated in the North Central part of Nigeria, and it lies between latitude $6^{0} 25^{\prime} \mathrm{N}$ and $8^{\circ} 8^{\prime} \mathrm{E}$ and between Longitude $7^{0} 47^{\prime} \mathrm{E}$ and $10^{\circ} 0^{\prime} \mathrm{E}$; and shares boundaries with five states namely: Nasarawa State to the north, Taraba State to the east, Cross river State to south, Enugu State to south -west and Kogi State to west. The mean annual rainfall shows a mark decrease from south to north $(100 \mathrm{~mm}-150 \mathrm{~mm})$. The raining season commences in April in the south, the length of the raining season varies from 90 days in the north to maximum of 200 days in the south. The dry season extends from October to early May and is marked by the hot north eastern harmattan wind. The population of the state is put at $4,253,641$ million (NPC, 2006) and has a land area $34,059 \mathrm{~km}^{2}$ spread over different ecological zones, its strategic location in the transitional belt between the forest area of the south and grass land of the south affords it the tremendous potential in Agriculture.

\section{Nature and Sources of Data}

The data for this study were obtained from primary sources. The primary data was generated directly from selected poultry farmers in Makurdi, Vandeikya and Oturkpo Local Government Areas of Benue State. Questionnaires were employed in the collection of the needed information on the respondents. The data collected covered relevant information on socio economic characteristics of poultry farmers and other important information relating to climate change adaptation strategies and climate adoption.

\section{Data analysis Techniques}

The data collected for this study were analyzed using both descriptive and inferential statistics. Descriptive statistics was used to describe the socio-economic characteristics of the respondents, adaptation strategies and level of awareness of climate change such as mean, frequency, percentage and Likert scale while the inferential statistics chi square test was used to achieved hypothesis which states there is no significant between selected socio-economic characteristics of poultry farmers and their perceived on climate change. 


\section{Socio-economic Characteristics of Respondents}

\section{RESULTS AND DISCUSSIONS}

Majority (48.6\%) of all the poultry farmers fall within 21-40 years age bracket. The average age of the respondents was 39.1 years in Benue state. These results imply that poultry farmers in the area were above the dependent age i.e. within the economically active age range, which means that poultry production is within the active productive class of close to 40 years. This further implies that if the occupation does witness the injection of young able men from now poultry production may be increased. These findings agree with the study of Adesiji et al. (2013) that found 40 years as means years of poultry farmers in Ondo State .

Majority of (52.5\%) of the respondents were females and $47.5 \%$ were males (Table 4.1 ). This implies that poultry production in Benue State is mainly dominated by female. This agrees with findings of Adesiji et al. (2013). This has implications for gender equality and calls for mainstreaming of men especially in agriculture where they constitute a bulk of the workforce.

The results showed that $19.6 \%$ of the respondents had no formal education about $24.6 \%$ had primary education with majority (36.5\%) had secondary education and $19.6 \%$ of them had tertiary education respectively in the study area. This is in line with the findings of Sluis (2007) who found poultry farmers have formal education in his studies. This means that respondents have one level of education to the other, an indication that school leavers were no longer waiting for white kola jobs rather than engaged themselves in poultry production in the study area.

Majority of the respondents (41.3\%) fell within the household size of 6 to 10, followed by $26.8 \%$ of the respondents which fell within the range of 1 to 5 household size (Table 4.1). The result shows that, the average household size was 9.. This result agrees with the finding of Adesiji et al. (2013) who found mean household size as 9. The result shows that $19.6 \%$ of the sampled poultry farmers were single, about $66.5 \%$ were married while $5.6 \%$ were divorced, $5.6 \%$ widowed and $2.8 \%$ widower respectively. The data of years of experience of respondents revealed that poultry farmers experience that lie between 6-10 and 11-15 with 26.8\% and $25.7 \%$ respectively constituting $52.5 \%$ with the mean age of 10 years, this is similar to the findings of (Sluis, 2007) who found the average years of experience in poultry production is 9 . The average start-up capital of the respondents was found to be $\mathrm{N} 85,542$, this may be due to the fact that majority of the respondents in small scale. Close to half (48.6\%) of the respondents practiced intensive system of poultry production in the study area, this may be explained by the fact that the system has much smaller impact on global warming than the free range production system (Sluis, 2007) 


\begin{tabular}{|c|c|c|}
\hline \multirow{2}{*}{$\frac{\text { Variable }}{\text { Age }}$} & Frequency & \multirow[t]{2}{*}{ Percentage } \\
\hline & & \\
\hline$\leq 20$ & 8 & 4.5 \\
\hline $21-40$ & 80 & 44.7 \\
\hline $41-60$ & 87 & 48.6 \\
\hline 61 and above & 4 & 2.2 \\
\hline TOTAL & 179 & 100 \\
\hline Mean; & $\overline{\mathrm{X}} ; \quad=$ & \\
\hline \multicolumn{3}{|l|}{ Sex } \\
\hline Male & 85 & 47.5 \\
\hline Female & 94 & 52.5 \\
\hline \multicolumn{3}{|l|}{ Marital status } \\
\hline Single & 35 & 19.6 \\
\hline Married & 119 & 66.5 \\
\hline Divorce & 10 & 5.6 \\
\hline Widow & 10 & 5.6 \\
\hline Widower & 5 & 2.8 \\
\hline Total & 179 & 100 \\
\hline \multicolumn{3}{|l|}{ Education Status } \\
\hline No formal education & 35 & 19.6 \\
\hline Primary & 44 & 24.6 \\
\hline Secondary & 65 & 36.3 \\
\hline Tertiary & 53 & 19.6 \\
\hline Total & 179 & 100 \\
\hline \multicolumn{3}{|l|}{ Household size } \\
\hline$\leq 5$ & 48 & 26.8 \\
\hline $6-10$ & 74 & 41.3 \\
\hline $11-15$ & 36 & 20.1 \\
\hline 16 and above & 21 & 11.7 \\
\hline Total & 179 & 100 \\
\hline Mean & 9.0 & \\
\hline \multicolumn{3}{|l|}{ Years of experience } \\
\hline$\leq 5$ & 50 & 27.9 \\
\hline $6-10$ & 48 & 26.8 \\
\hline $11-15$ & 46 & 25.7 \\
\hline 16 and above & 35 & 19.6 \\
\hline Total & 179 & 100 \\
\hline \multicolumn{3}{|l|}{ Mean $=10.51$} \\
\hline \multicolumn{3}{|l|}{ Start- up capital } \\
\hline$\leq 100000$ & 139 & 77.7 \\
\hline $100001-200000$ & 27 & 15.1 \\
\hline $200001-300000$ & 6 & 3.4 \\
\hline 300001 and above & 7 & 3.9 \\
\hline Total & 179 & 100 \\
\hline Mean; $\quad=85,542.3$ & & \\
\hline \multicolumn{3}{|l|}{ System of poultry Mgt } \\
\hline Intensive & 87 & 48.6 \\
\hline Semi -intensive & 30 & 16.7 \\
\hline Extensive & 62 & 34.7 \\
\hline
\end{tabular}




\section{Perception and Awareness of Climate Change by the Respondents}

This section presents the perception and awareness of the poultry farmers about climate change in the study area. About $26.8 \%$ of the respondents had been aware of climate change for at least 6 years and at most 10 years in the study area; about $27.9 \%$ of the respondents were aware of climate change for at most five (5) years, about $25.7 \%$ were aware of climate change for at least 11 years and at most 15 years while about $19 \%$ of the respondents were aware climate change for 16 years and above with the mean years of awareness as 10.51 . There is tendency of the years of awareness of climate change to have positive effect on the adaptation strategies used by the poultry farmers, that is, the higher the number of years of awareness the more experienced the farmer in coping with the change in climate. This agrees with the findings of Adesiji et al. (2013) who found that farmers' awareness of changes in climate attributes (temperature and precipitation) is important for adaptation decision making.

Table 2: Frequency Distribution of Respondents by their Years of Awareness of Climate Change

\begin{tabular}{lcc}
\hline Awareness (years) & Frequency & Percentage \\
\hline$\leq 5$ & 50 & 27.9 \\
$6-10$ & 48 & 26.8 \\
$11-15$ & 46 & 25.7 \\
16 and above & 35 & 19.6 \\
Total & $\mathbf{1 7 9}$ & $\mathbf{1 0 0}$ \\
Mean $=\mathbf{1 0 . 5 1}$ & & \\
\hline
\end{tabular}

Source: (Computed from field data, 2019)

Farmers perception according to Level of Awareness and Observed climatic Variation

Table 3 shows that $90.9 \%$ of the respondents agreed that they are aware of climate change; this indicates that the majority of the poultry farmers in the study area have noticed variation in climatic elements and are likely to observe how it will affect the rate of survival and performance of their poultry production. On the observed climatic variation, the table depicts that $85.9 \%$ of the respondents all agreed that temperature fluctuate in the study area. In similar vein, $72.6 \%$ of the respondents observed increased sunshine intensity in the study area and $76.3 \%$ agreed that distribution of rainfall follows normal distribution, while $80.5 \%$ of the respondents agreed that global warming has effect on poultry production respectively in the study area. Temperature fluctuation and increased sunshine intensity has negative consequence on poultry production resulting in high mortality of the chickens, low egg production and low feed in take with low production (ICAR, 2010) 
Table3: Perception of Respondents According to level of Awareness and Observed Climatic

\begin{tabular}{|c|c|c|c|c|}
\hline \multirow{3}{*}{ Level of Awareness/Observed } & \multicolumn{3}{|c|}{ Variation } & \multirow{3}{*}{$\begin{array}{l}\mathrm{D} \\
\text { Frq (\%) }\end{array}$} \\
\hline & SA & A & SD & \\
\hline & Frq & $\operatorname{Frq}(\%)$ & $\operatorname{Frq}(\%)$ & \\
\hline Awareness/climate variation & $112(62.5)$ & $51(28.4)$ & $11(6.3)$ & $5(2.8)$ \\
\hline Temperature fluctuation & $100(56.3)$ & $53(29.6)$ & $17(9.3)$ & $9(4.8)$ \\
\hline Sunshine intensity increases & $86(48.2)$ & $44(24.4)$ & $29(16.2)$ & $20(11.2)$ \\
\hline $\begin{array}{l}\text { Rainfall distribution follows regular } \\
\text { Pattern }\end{array}$ & $102(57.1)$ & $34(19.2)$ & $24(13.2)$ & $19(10.5)$ \\
\hline $\begin{array}{l}\text { Global warming has effect on poultry } \\
\text { production }\end{array}$ & $94(52.3)$ & $54(30.2)$ & $26(14.6)$ & $5(2.9)$ \\
\hline
\end{tabular}

Source: (Computed from field data, 2019)

\section{Testing of hypothesis}

\section{Ho1: There is no significant relationship between selected socio-economic characteristics of poultry farmers and their perceived effects on climate change}

The result of chi-square analysis in table 6 shows that there is a significant relationship between respondents' socio - economic characteristics and perception of poultry farmers on effects of climate change on poultry production since $\mathrm{p}>0.05(\mathrm{r}=0.544, \mathrm{p}=0.000)$. The $\mathrm{r}$ square value of 0.544 shows a good relationship between socio- economic characteristics and perception of poultry farmers on effects of climate change on poultry production. This implies that socioeconomic characteristics influence the perception of the poultry farmers on the effect of climate change on poultry production in the study area. This may be explained on the basis of the fact that majority of the men and women, the young and old, the literate and illiterate as well as people that practice different systems of poultry farming in the area are aware of climate change in the study area. This means that the null hypothesis which states that selected socio-economic characteristics of respondents do not have significant relationship was rejected

Table 4: Relationship between Socio-economic Characteristics of Respondents and perceived Effect of Climate Change on Poultry Production.

\begin{tabular}{lcccccc}
\hline variables & $\mathbf{N}$ & $\mathbf{X}$ & $\mathbf{S D}$ & $\mathbf{R}$ & sig & Decision \\
\hline $\begin{array}{l}\text { selected } \\
\text { socio-economic characteristics }\end{array}$ & 179 & 1.6 & 0.63 & 0.544 & 0.000 & Ho \\
\begin{tabular}{l} 
perceived years of awareness \\
\hline
\end{tabular} & 179 & 1.62 & 0.59 & 0.544 & 0.000 & Rejected \\
\hline
\end{tabular}

Source: (Computed from field data, 2019)

\section{CONCLUSION}

This paper assessed effect of climate change on poultry production in Benue State. The objective were to described of socio-economic characteristics of poultry farmers in the study area, level of awareness of climate change and perceived effects of climate change in the state. The study revealed that the mean age of poultry farmers in the study area was 39.1 years. This means poultry famers in the study area are above dependent age and could carry poultry production on their own. The mean years of awareness of climate was 10.51 years means that poultry farmers in the study have the aware of climate change for long time. The result further revealed shows that $90.9 \%, 85.9 \%, 72.6 \%, 76.3 \%$ and $80.5 \%$ agreed that there was climate change, temperature fluctuation, sunshine intensity increases, rainfall follow normal distribution and global warming effect on poultry production respectively. The result showed 
that there is significant relationship between socio-economic characteristics of respondents and perception of poultry farmers on the effects of climate change on poultry production since $\mathrm{p}>0.05(\mathrm{r}=.544, \mathrm{p}=.000)$

\section{References}

Adesiji, G.B., Tyabo, I.S., Bolarin, O. Ibrahim, M. and Baba, S. T (2013) :Effects of Climate Change on Poultry Production in Ondo State, Ngreia. Ethiopian Journal of Environmental Studies and Management,6(3):243-248

Demeke, S. (2004), Egg Production and Performance of local white leghorn hens underintensive and rural household conditions in Ethiopia. LRRD 16: 2

Elijah, O.A. and Adedapo, A. (2006), The effect of climate on poultry productivity in Ilorin Kwara State, Nigeria. International journal of poultry Science, 5(11), 1061-1068

Guis, H., Caminade, C., Calvete, C., Morse, A.P.,Tran, A. and Baylis, M. (2011), Modeling The effects of past and future climate on the risk of blue tone emergence in Europe. Journal of Rural Sociology Interface 10. 1098/rsif.2011.0255

Khanal, R.C. (2009). Climate change and organic agriculture. The Journal of Agriculture and Environment 10, 100109, Review paper.

India Council of Agricultural Research (ICAR),2010 -11 annual Report Pp 13.

Olanrewaju, H.A., Purswell, J.L., Collier, S.D. and Branton, S.L. (2010), Effect of Ambient Temperature and Light Intensity on Growth Performance and Carcass Characteristics of Heavy Broiler Chickens at 56 Days of Age. International Journal of Poultry Science, 9(8), 720-725.

Odjugo, P. A. O. (2009). Quantifying the cost of climate change impact in Nigeria: Emphasis on wind and rainstorms. Journal of Human Ecology, 28(2), 93-101.

Oyekale, A. S., Bolaji, M .B. \& Olowa, O. W. (2009). Effects of climate change on crop production and vulnerability in Nigeria. Agricultural Journals 4(2), 77-85.

Sluis, W. V. (2007), Intensive poultry Production. World poultry.Retrieved from WWW. World poultry.net on 25 th/092019. $2.35 \mathrm{pm}$ 